\title{
Using Unmanned Aerial Vehicles (UAV) for mornitoring the construction progress of Ho Chi Minh City urban railway project
}

- Nguyen Huu Nhat ${ }^{1}$

- Dao Minh Tam²

- Le Van Trung ${ }^{1}$

- Le Trung Chon ${ }^{1}$

${ }^{1}$ Ho Chi Minh city University of Technology, VNU-HCM

${ }^{2}$ Geomatics Center,VNU-HCM

(Manuscript Received on April 22 ${ }^{\text {nd }}, 2015$, Manuscript Revised June 01 ${ }^{\text {st }}$, 2015)

\begin{abstract}
This paper describes a new approach for monitoring the construction progress of the Urban Railway Construction Project "Metro line1 - Ben Thanh - Suoi Tien" by using Unmanned Aerial Vehicles (UAV) to capture high resolution imagery at different stages of the project. The advantage of the AscTec Falcon 8 systems lies in their high flexibility and efficiency in capturing the surface of an area from a low flight altitude. In addition, further information such as
\end{abstract} orthoimages, elevation models and $3 D$ objects can easily be processed by Pix4Dmapper software. The Ground Control Points (GCPS) and GIS data were used to compare the achieved accuracy of UAV method. This study shows the feasibility of using an UAV system for acquiring the high resolution aerial images and the new opportunities for managing construction progress over time.

Key words: UAV, GIS, VN2000, Pix4Dmapper.

\section{INTRODUCTION}

To develop remote imaging techniques that is able to provide high resolution, real-time images for social applications and economic development, as well as for national security applications is important items of Viet Nam's strategy in space research and applications until 2020 officially approved by the Prime Minister in June 2006, according to the Decision number
137/2006/QĐ-TTg. However, Viet Nam has been mainly using satellite images (taken from $500 \mathrm{~km}$ to $900 \mathrm{~km}$ altitudes) and images taken from aircraft for altitudes from $300 \mathrm{~m}$ to $1.000 \mathrm{~m}$. The high-resolution imaging system based on UAVs being capable of taking images of low altitudes ranging from $10 \mathrm{~m}$ to $300 \mathrm{~m}$ is highly demanded and promisingly applied in many

\section{Trang 104}


social-economic applications, such as: hydraulic dam observation, urban management, environmental observation,...

Satellite and Airborne image survey are valid techniques to capture data in broad area that the required measurement accuracy depends on relation to the object/area size. Recent experimental studies [1-6] showed that the shortcomings of above-mentioned imaging techniques can be overcome by the remote imaging system based upon unmanned air vehicle (UAV).

This study presents the experimental results of UAV for monitoring the construction progress of the Urban Railway Construction Project "Metro line1 - Ben Thanh - Suoi Tien". The paper also contributes a new way to build up high resolution images for small and constrained areas in real time. Therefore, the use of UAVs is an opportunity for surveying that will be used where a need of high accuracy is required and fast data capturing is demanded.

\section{DATA AQUISITION AND USED METHODS}

\subsection{Test Areas}

To monitoring the construction process, the aerial images of the 20.9 ha Depot area (20.9 ha) and the construction line $(17.2 \mathrm{~km})$ are captured. The imaging frequency is every 3 months. All of images are referenced to Coordinate Systems VN2000 (See figure 1).

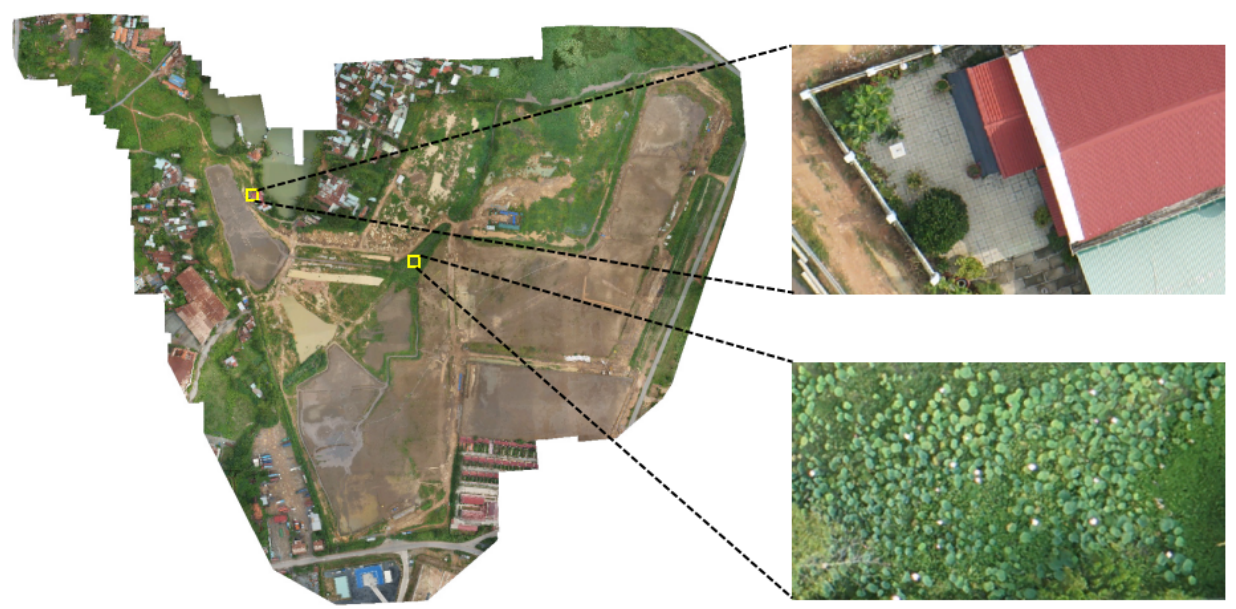

Figure 1. Overview image of the site to take aerial photographs and two small areas of high resolution images were taken from camera: Sony NEX-5N 


\subsection{Used Systems for the UAV Method}

The UAV is developed using a commercially available, namely called AscTec Falcon 8 of which 3 main components are a remote control, the flight control software and the octocopter itself (Figure 2). Camera Sony NEX-5N (16.1 megapixel) is used for remote imaging system actively with stabilized camera mount. The Falcon 8 major technical specifications include: Flight time: 20 - 30 minutes (limited by battery capacity); Image transfer frequency $(5.8 \mathrm{GHz})$; Control signal frequency from ground station $(2.4 \mathrm{GHz})$ and Live video feed to the Mobile Ground Station.

The UAV method for the acquisition of geodata is based on a good and appropriate flight planning. In Figure 3 the flight planning for the metro line 1 is shown, using the provided software of the UAV manufacturer (AscTec Auto Pilot Control - Ascending Technologies).

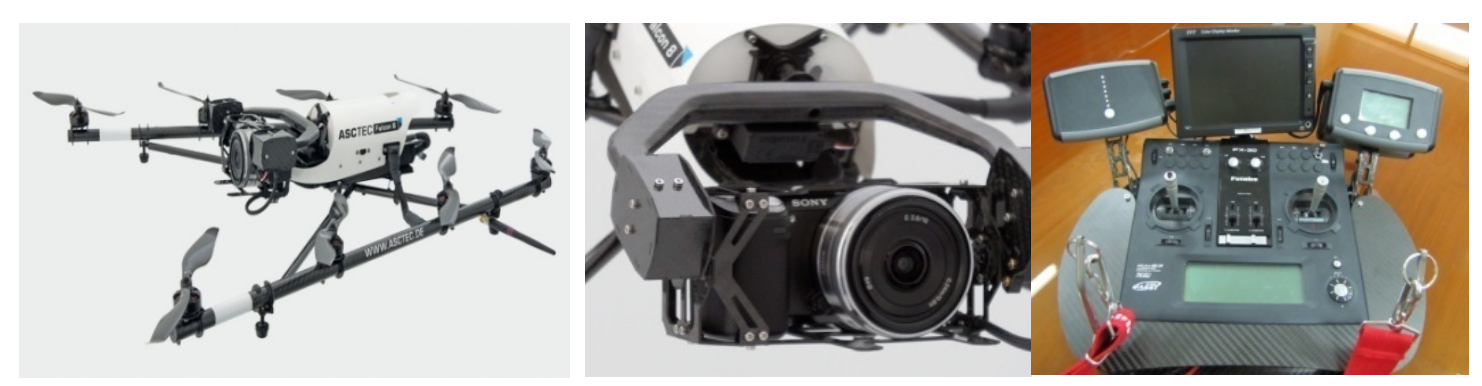

Figure 2. UAV (Falcon) and facilities used for aerial photography

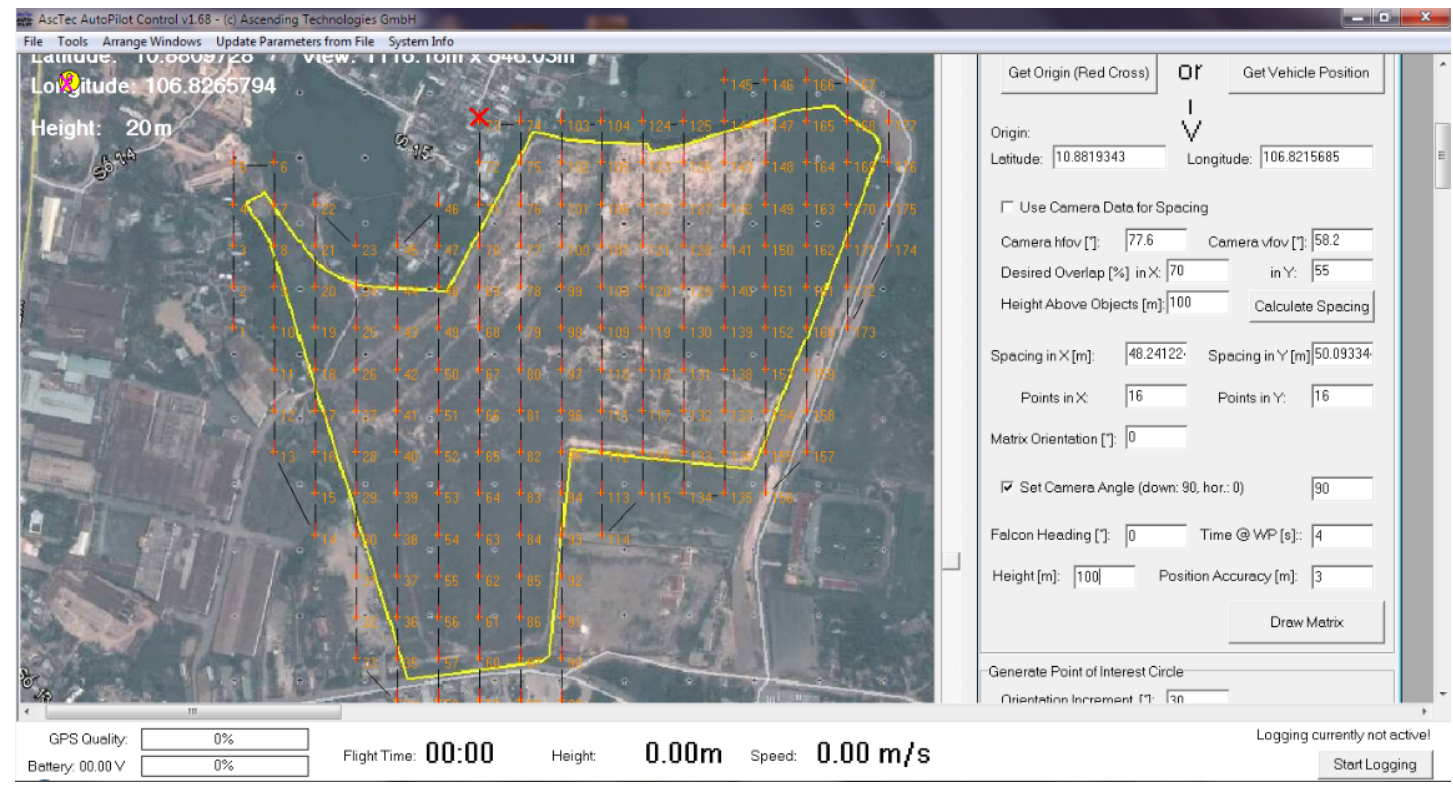

Figure 3. Flight planning of the metro line by using AscTec AutoPilot Control

\section{Trang 106}


The UAV has been experimented for the observed area and results showed that the dependence of horizontal resolution as function of flight altitudes.

From experimental results, it was necessary to set up a reference station during data acquisition by UAV for monitoring construction progress of the Metro line. With the help of these flight plans the UAV is steered autonomously over predefined routes. Along these paths, aerial images are taken at $100 \mathrm{~m}$ for altitude, $65 \%$ overlap along track (flight direction) and 50\% overlap across track. The Falcon 8 could be planned to operate in two different modes: (1) autonomously flight and take images at prescribed GPS-defined locations (2) manually flight control (real-time images observed) and take images at preferred locations. In order to transform the acquired data into the national coordinate reference system (VN2000), control points from official topographical surveying are required. To determine the relationship between altitude capture and image resolution, we conducted a flight test taken at different heights $(30 \mathrm{~m}, 100 \mathrm{~m}$ and $150 \mathrm{~m})$. The test results are shown in Table 1.

\section{RESULTS}

The mission (flight and data acquisition) is planned in the lab with AscTec Auto Pilot Control software. Thus fixing the image scale and camera focal length, the flying height is derived. The take-off and landing operations are strictly related to the characteristics of Falcon 8 and functions of remote controller. During flight, the data link, camera control, video link, status display and the controls for the system itself are integrated into the Mobile Ground Station. Status display shows real-time flight data such as position, speed, attitude and distances, GPS observations, battery status, etc.

All the image processing steps are integrated into image processing software Pix4Dmapper. The image geolocation is displayed in the table 2 that shows the latitude and the longitude value; GPS height and the yaw, pitch, roll values.

In order to improve the geolocalisation accuracy of the experimental results, 11 Ground Control Points (GCPs) are used and at least 2 GCPs are added per image (Figure 3, Figure 4)

Table 1. The relationship between image resolution and height of UAV

\begin{tabular}{|c|c|c|c|c|c|}
\hline Resolution (cm) & $\begin{array}{c}\text { Flight height } \\
(\mathbf{m})\end{array}$ & $\begin{array}{c}\text { Overlap X } \\
(\%)\end{array}$ & $\begin{array}{c}\text { Overlap Y } \\
(\%)\end{array}$ & $\begin{array}{c}\text { Number of } \\
\text { photoes }\end{array}$ & Region (mxm) \\
\hline 1.1 & 30 & 65 & 60 & 121 & $200 \times 100$ \\
\hline 2.9 & 100 & 65 & 60 & 36 & $300 \times 200$ \\
\hline 2.9 & 100 & 85 & 80 & 56 & $300 \times 200$ \\
\hline 5.5 & 150 & 65 & 60 & 30 & $400 \times 300$ \\
\hline
\end{tabular}


Table 2. Images properties of one single flight

\begin{tabular}{|c|c|c|c|c|c|c|}
\hline Image & Latitude & Longitude & GPS Height & Yaw & Pitch & Roll \\
\hline DSC02283.JPG & 10.879617 & 106.818831 & 101.887 & -2.888 & 3.175 & 0.051 \\
\hline DSC02284.JPG & 10.880052 & 106.818816 & 102.087 & -0.456 & 0.147 & 359.627 \\
\hline DSC02285.JPG & 10.880504 & 106.818816 & 102.372 & -0.008 & 0.127 & 359.579 \\
\hline DSC02286.JPG & 10.880958 & 106.818815 & 101.814 & -0.345 & 0.503 & 359.778 \\
\hline DSC02287.JPG & 10.880966 & 106.819263 & 101.342 & 0.058 & 4.189 & 359.621 \\
\hline DSC02288.JPG & 10.880521 & 106.819271 & 100.261 & -0.802 & 6.067 & 359.604 \\
\hline DSC02289.JPG & 10.880073 & 106.819276 & 100.24 & -0.283 & 7.639 & 0.281 \\
\hline DSC02290.JPG & 10.879621 & 106.819277 & 100.709 & -3.612 & 8.794 & 0.484 \\
\hline DSC02291.JPG & 10.87916 & 106.819261 & 100.147 & 2.052 & 6.997 & 359.101 \\
\hline DSC02292.JPG & 10.878276 & 106.81927 & 100.071 & -0.22 & 7.56 & 359.922 \\
\hline
\end{tabular}

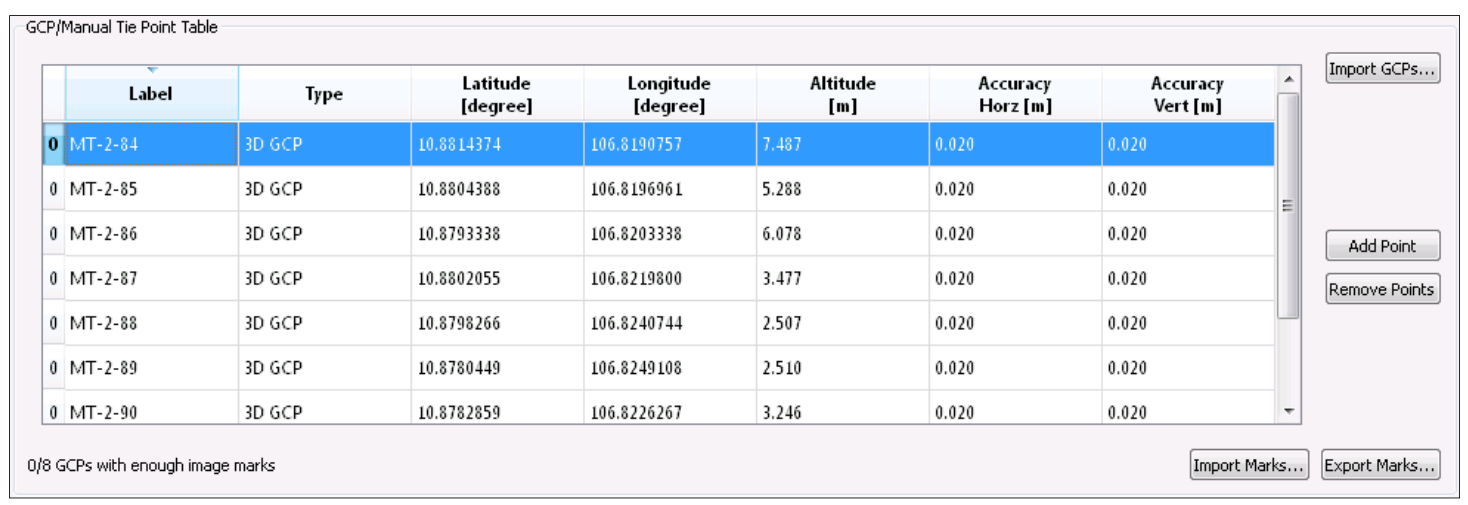

Figure 3. The GCPs in the images are used in the experiment

\section{Trang 108}




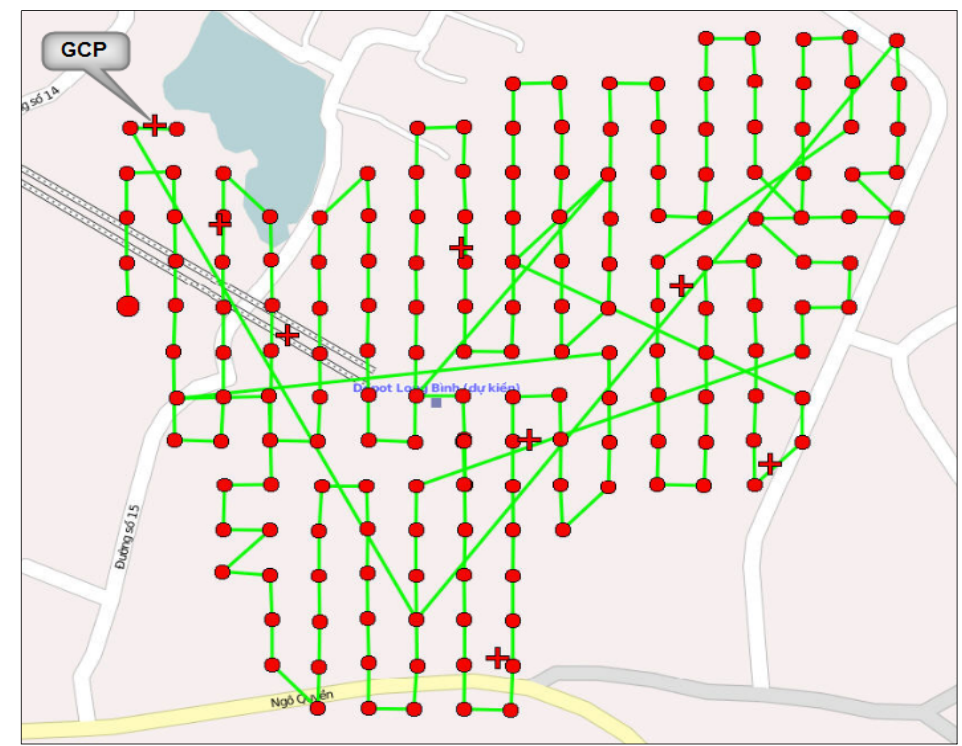

Figure 4. The layout of GCP for capturing by UAV

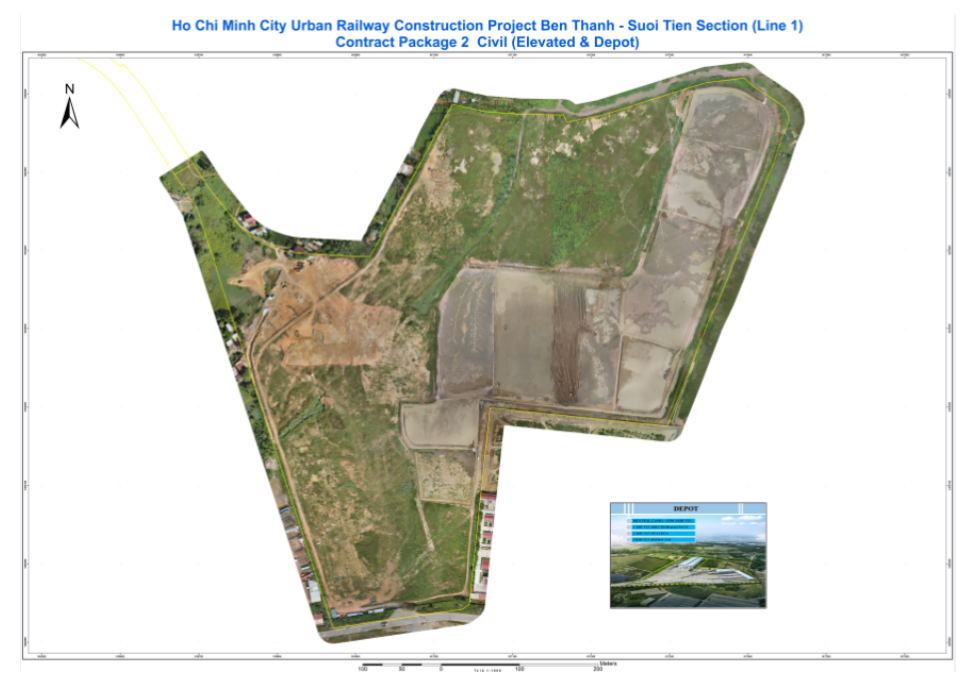

Figure 5: Depot area of metro line

During local processing with Pix4Dmapper, depending on the number of images, the number and type of output generated, the final result files are professional accurate 2D maps and 3D models. As image is georeferenced, it can be displayed by ArcGIS (ESRI) that allows to quickly and correctly evaluate the success and quality of data acquisition by UAV for monitoring construction progress of the Metro line. Figure 5 shows depot area of metro line generated from images of Camera Sony NEX-5N that is mounted on the Falcon 8.

Figure 6 shows the elevated viaduct with locations of piers, bridges, and stations that GIS is used to give are illustration pictures of designed location 


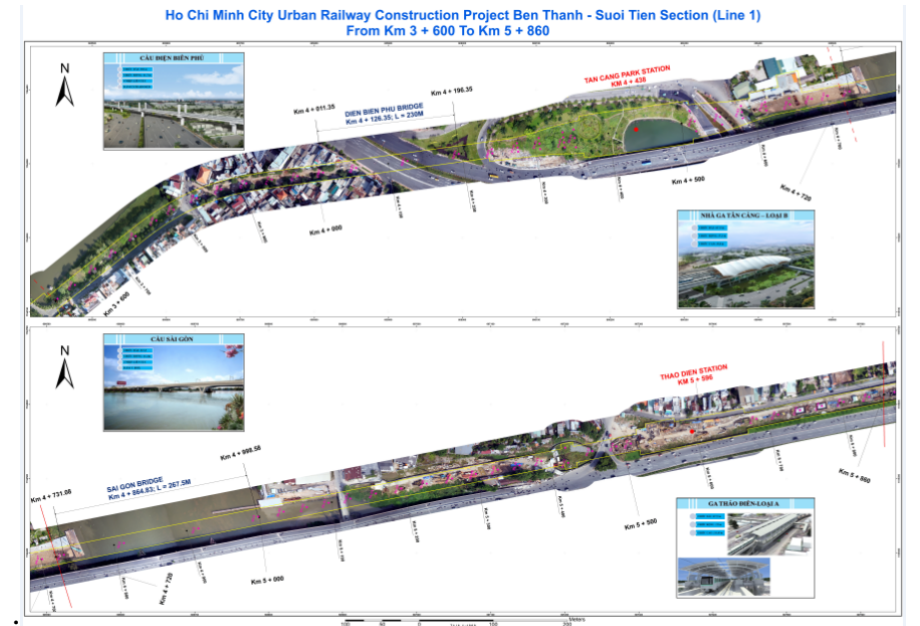

Figure 6: Elevated viaduct of metro line with illustration pictures of bridges and stations

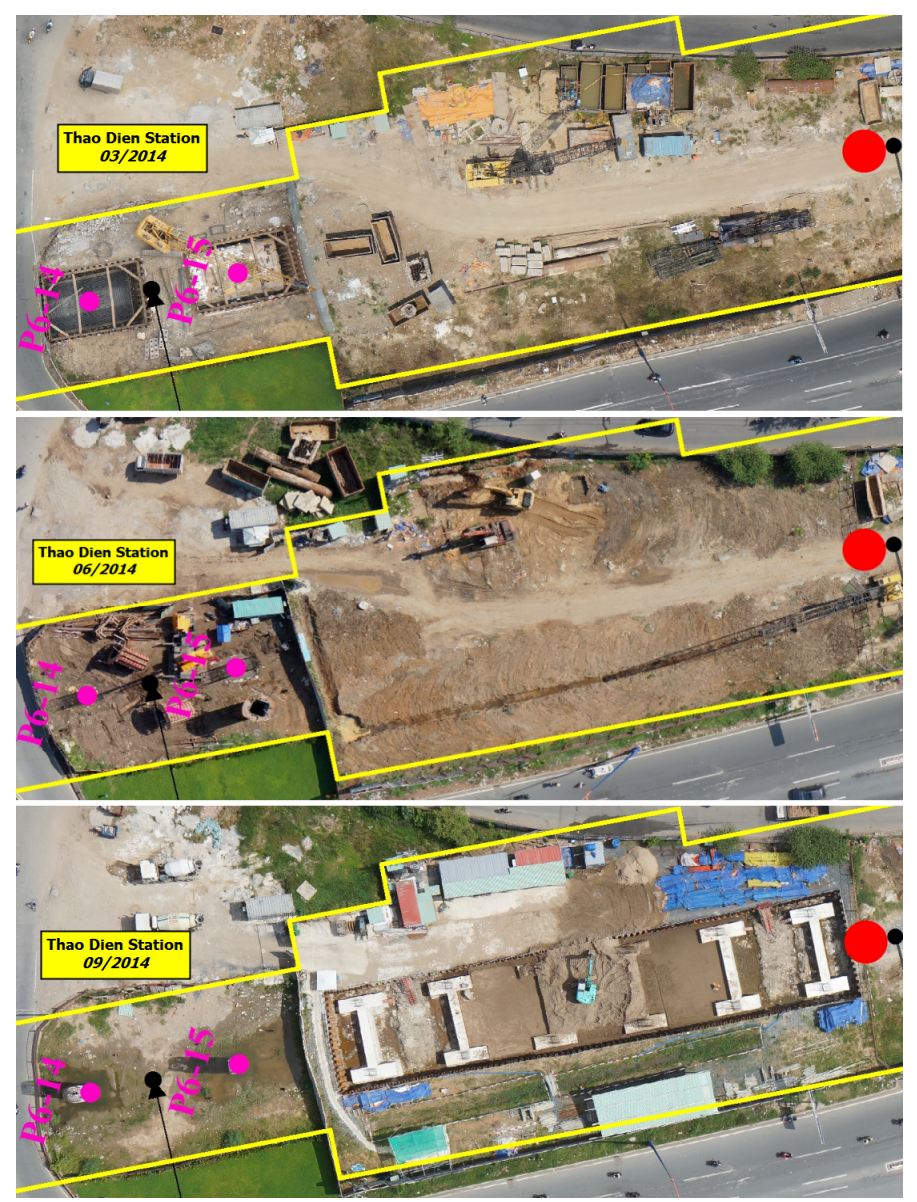

Figure 7. The construction progress related to Thao Dien station

\section{Trang 10}


Feasibility of using an UAV system for managing construction progress over time is showed by Figure 7. The necessary information related to Thao Dien station and scope of works to be showed by progress photographs of UAV that is carried out once in every 3 months during construction progress of metro line.

In addition, Pix4Dmapper image processing software can permit to create DSM model and 3D images for large scale area of metro line based upon overlapped images.

\section{CONCLUSIONS}

The achieved accuracy of data acquisition by UAV for monitoring construction progress of the Metro line depends on the flight height and have a $2 \mathrm{D}$ coordinate quality of $2.9 \mathrm{~cm}$ (image resolution) when the height of UAV is $100 \mathrm{~m}$.
The optimal height of capture is $100 \mathrm{~m}$. The accuracy can be increased by using additional information of data from Ground Control Points (GCPs). This problem will be define in next our research when GCP network of construction is finished. Experimental results are very promising and clearly demonstrated the capacity of UAV-based remote imaging system to provide high-resolution image (with resolution lower than $3 \mathrm{~cm}$ in horizontal plane and lower than $20 \mathrm{~cm}$ in altitude) for for managing construction progress over time with quite low cost. This opens a new way that is suitable to be used in addition to the standard surveying methods in order to gain further data through the acquired images such as overview images or ortho-images and 3D models.

\section{Ứng dụng thiết bị bay không người lái (UAV) theo dõi tiến độ xây dựng dự án đường sắt đô thị Thành phố Hồ Chí Minh}

- Nguyễn Hữu Nhật ${ }^{1}$

- Đào Minh Tâm²

- Lê Văn Trung ${ }^{1}$

- Lê Trung Chơn ${ }^{1}$

${ }^{1}$ Ho Chi Minh city University of Technology,VNU-HCM

${ }^{2}$ Geomatics Center,VNU-HCM 


\section{TÓM TẮT}

Bài báo này trình bày một tiếp cận mới trong việc theo dõi tiến độ dụ án xây dựng dụ̣ án xây dựng đường sắt đô thị cụ thể là tuyến metro số 1 - Bến Thành - Suối Tiên bằng việc sử dụng thiết bị bay không người lái (UAV) bay chụp ảnh quá trình xây dựng dụ án theo từng giai đoạn với độ phân giải cao. Ưu điểm của hệ thống chụp ảnh AscTec Falcon 8 là tính cơ động và khả năng chụp ảnh bề mặt từ độ cao bay thấp. Ngoài ra, việc thành lập ảnh trực giao (bình

Từ khóa: Thiết bị bay không người lái (NAV), GIS, Hệ tọa độ VN2000, Phần mềm Pix4Dmapper

\section{REFERENCES}

[1]. Harintaka, Subaryono, A. Susanto, Hartono, Assessment of Low Cost Small Format Aerial Photogrammetry for Cadastral Mapping, 7th FIG Regional Conference on Spatial Data Serving People: Land Governance and the Environment - Building the Capacity, 1922 October 2009, Hanoi, Vietnam

[2]. P. Patias, C. Saatsoglou-Paliadeli, O. Georgoula, M. Pateraki, A. Stamnas, N. Kyriakou, Photogrammetric documentation and digital representation of the macedonian palace in verginaaegeae, XXI International CIPA Symposium, 01-06 October 2007, Athens, Greece

[3]. J. Everaerts, The Use of Unmanned Aerial Vehicles (UAVs) for Remote Sensing and Mapping, The International Archives of the Photogrammetry, Remote Sensing and Spatial Information Sciences. Vol. XXXVII. Part B1. Beijing 2008

[4]. A. Lucieer, S. Robinson and D.J. Turner, Using an Unmanned Aerial Vehicle (UAV) đồ ảnh), mô hình độ cao số và các đồi tượng $3 D$ được thực hiện dễ dàng bằng phần mềm xử lý ảnh Pix4Dmapper. Các điểm khống chế mặt đất (GCP) và dũ̃ liệu GIS được sưr dụng để đánh giá độ chính xác các dữ liệu thành lập bằng phương pháp UAV. Nghiên cứu này cho thấy khả năng áp dụng hệ thống UAV trong việc thu nhận ảnh độ phân giải cao và quản lý tiến độ xây dựng theo thời gian. for Ultra-High Resolution Mapping of Antarctic Moss Beds, Proceedings of the Australasian Remote Sensing and Photogrammetry Conference, September 2010, Alice Springs (2010) [Non Refereed Conference]

[5]. M. Manyoky, P. Theiler, D. Steudler, H. Eisenbeiss, Unmanned aerial vehicle in cadastral applications, International Archives of the Photogrammetry, Remote Sensing and Spatial Information Sciences. Vol. XXXVIII-1/C22. Conference on Unmanned Aerial Vehicle in Geomatics, Zurich, Switzerland, 2011

[6]. M. Bláha, H. Eisenbeiss, D. Grimm, P. Limpach, Direct georeferencing of UAVs, International Archives of the Photogrammetry, Remote Sensing and Spatial Information Sciences. Vol. XXXVIII-1/C22. Conference on Unmanned Aerial Vehicle in Geomatics, Zurich, Switzerland, 2011

\section{Trang III}

